Article

\title{
Enlargement of a Modular System-Synthesis and Characterization of an $s$-Triazine-Based Carboxylic Acid Ester Bearing a Galactopyranosyl Moiety and an Enormous Boron Load
}

\author{
Martin Kellert ${ }^{1}\left(\mathbb{D}\right.$, Peter Lönnecke ${ }^{1}$, Bernd Ried1 ${ }^{2}$, Johannes Koebberling ${ }^{2}$ \\ and Evamarie Hey-Hawkins ${ }^{1, *(D)}$ \\ 1 Institute of Inorganic Chemistry, Faculty of Chemistry and Mineralogy, Leipzig University, Johannisallee 29, \\ 04103 Leipzig, Germany \\ 2 Bayer AG, Aprather Weg 18A, 42113 Wuppertal, Germany \\ * Correspondence: hey@uni-leipzig.de; Tel.: +49-341-97-36151 \\ Academic Editors: Igor B. Sivaev, Narayan S. Hosmane and Bohumír Grúner \\ Received: 19 August 2019; Accepted: 30 August 2019; Published: 10 September 2019

\begin{abstract}
The amount of boron accumulated in tumor tissue plays an important role regarding the success of the boron neutron capture therapy (BNCT). In this article, we report a modular system, combining readily available starting materials, like glycine, 1,3,5-triazine and the well-known 9-mercapto-1,7-dicarba-closo-dodecaborane(12), as well as $\alpha$-D-galactopyranose for increased hydrophilicity, with a novel boron-rich tris-meta-carboranyl thiol.
\end{abstract}

Keywords: boron neutron capture therapy; carborane; s-triazine; cancer therapy; modular system

\section{Introduction}

Since the early 1950s, boron neutron capture therapy (BNCT) is regarded as a very promising method for cancer treatment $[1,2]$. The binary therapy uses non-toxic components, boron-10-containing reagents and thermal or epithermal neutrons, to produce cytotoxic species, which are able to destroy malignant tissue. Boron-10-containing drugs linked to a tumor-selective functional group to address the cancer site are highly advantageous [3-10]. Ideally, the non-toxic bioconjugate shows selective accumulation and retention in the malignant tissues in the required amount of $10-30 \mu \mathrm{g} / \mathrm{g}$ tumor and can, subsequently, be irradiated with thermal or epithermal neutrons $[3,11,12]$. It depends on the drug carrier if the BNCT agent is just accumulated in the tumor tissue or internalized into the cancer cells; internalization increases the efficacy of this cancer treatment [10,13-27]. Following the neutron capture event, the generated particles are lithium and helium nuclei ( $\alpha$ particles) and possess a high linear energy transfer (LET) $[3,28,29]$. These high-energy particles with a mean free path of about 5 to $10 \mu \mathrm{m}$ reveal their destructive action only in a limited area [3,8,9]. Although the combination of suitable boron-rich molecules with tumor-selective moieties allows a very selective tumor treatment, which only affects malignant and spares normal tissue $[13,15,17,23-25,30]$, there are still some relevant challenges, including, but not limited to, the selectivity of the chosen biomolecules for a specific tumor type, the required boron-10 concentration in cancer cells, the water solubility of the final bioconjugate, and the neutron beam quality [31], which are the focus of recent studies [16,25-27,32-37].

Due to the necessity of high boron concentrations in malignant tissue, research for BNCT drugs with a high boron content is highly demanded [13-15,17,23,38-42]. There are already many strategies employed to develop specific shuttle systems; however, some are associated with undesired cytotoxic side effects (polycationic compounds) [42], low yields in synthesis (encapsulation of boron compounds in liposomes) [13], low selectivity (cell-penetrating peptides [17], dendrimeric BNCT drugs [14]) or 
deboronation reactions (application of ortho-carboranes) [43,44]. Recently, we reported the synthesis of a modular system to prepare potential precursor molecules for novel BNCT agents [45-47]. Here, we describe a modified modular system for the preparation of a carboxylic acid derivative with a very high boron load (Figure 1) suitable for coupling with a variety of biomolecules.

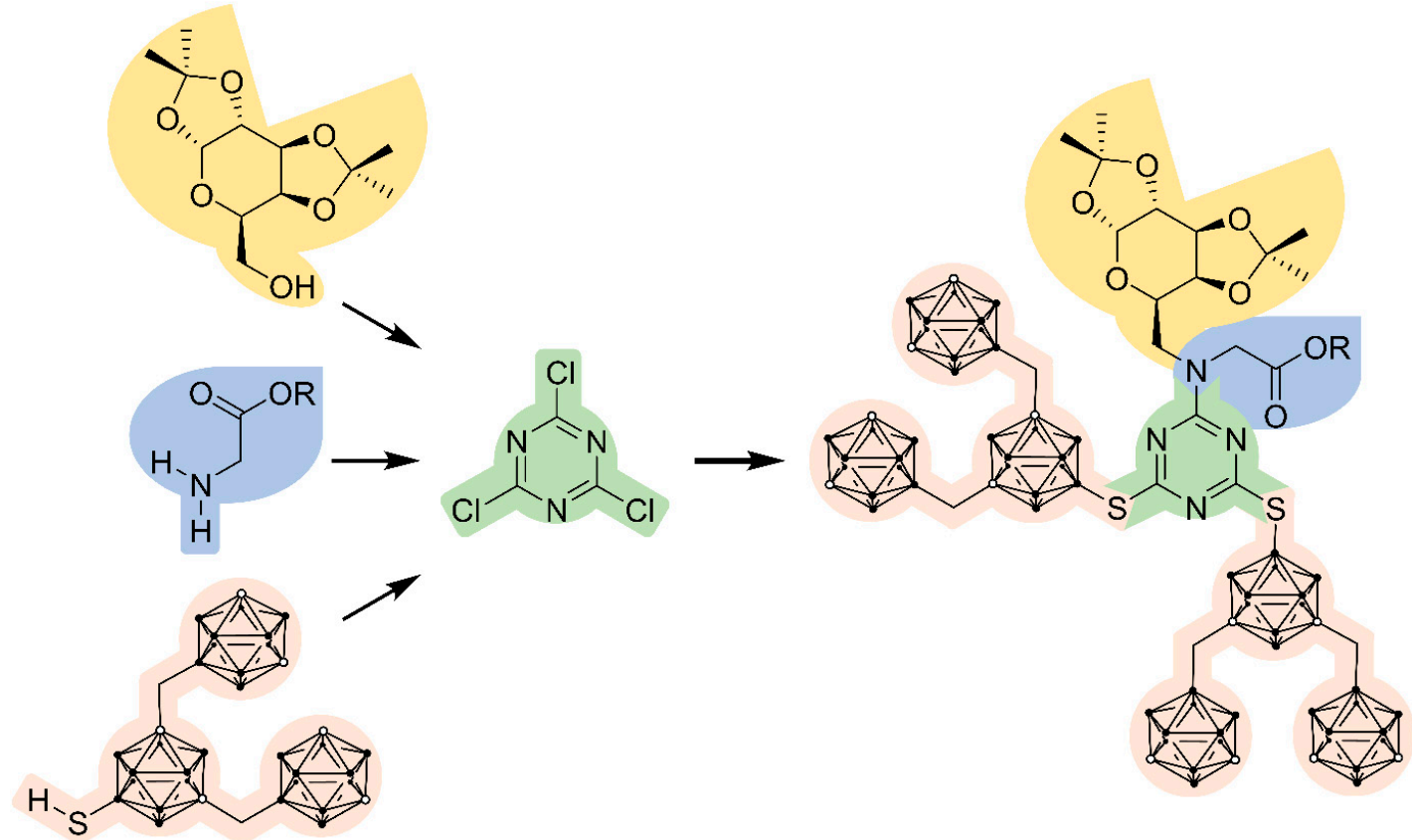

Figure 1. Illustration of the modular system incorporating an $\alpha$-D-galactopyranosyl moiety (yellow), protected glycine (blue), a tris-cluster derivative of 9-mercapto-1,7-dicarba-closo-dodecaborane(12) (pale red) and cyanuric chloride (green) as core; $\mathrm{R}=$ tert-butyl.

\section{Results and Discussion}

The application of carboranes with nucleophilic carbon atoms, like carboranyl lithium compounds or Grignard reagents obtained from bromomethyl-ortho-carborane, is widespread [48-53]. For C-C bond formation, the Kumada coupling reaction between Grignard reagents and organohalides with palladium catalysts is very useful [54-56], and can also be extended to carborane derivatives. Thus, Kumada-like reactions are known for 9-iodo-1,7-dicarba-closo-dodecaborane (1) and even for tetraiodinated derivatives [57-59], and are also employed here for the preparation of boron-rich derivatives.

The iodination reaction of ortho- and meta-carboranes at the 9-position is well-known [60-64], so the synthesis of the corresponding derivative $\mathbf{1}$ was straightforward (Scheme 1, step a). For the synthesis of the bromomethyl derivative 3 , based on the metabolically stable meta-carborane, only a few examples are known [65]. 


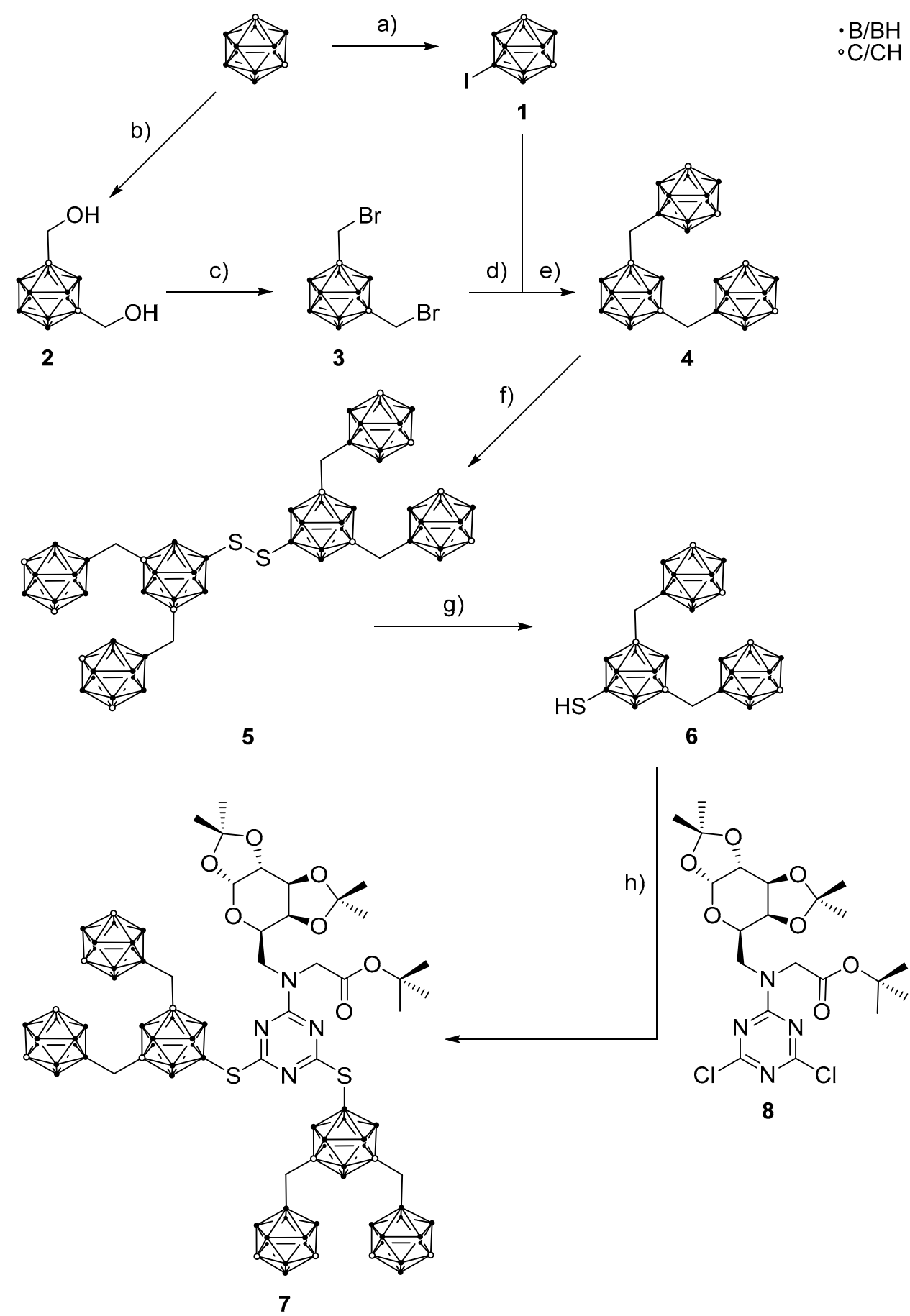

Scheme 1. Preparation of tert-butyl-N-\{4,6-bis[(1,7-dicarba-closo-dodecaboran-9-ylmethyl)1,7dicarba-closo-dodecaboran-9-ylthio]-1,3,5-triazin-2-yl\}-N-(1', 2' :3', 4' -di-O-isopropylidene-6' -deoxy- $\alpha$-Dgalacto-pyranos-6'-yl)glycinate (7). a) $\mathrm{I}_{2}, \mathrm{AlCl}_{3}, \mathrm{CH}_{2} \mathrm{Cl}_{2}, \mathrm{rt}, 2 \mathrm{~d}, 92 \%$ [62,63]; b) paraformaldehyde, n-BuLi, tetrahydrofuran (THF), rt, overnight, 89\%; c) $\mathrm{Br}_{2}, \mathrm{PPh}_{3}$, benzene, reflux, $46 \mathrm{~h}, 95 \%$ [64-66]; d) from 3- $\mathrm{Mg}$, THF, reflux, $2 \mathrm{~h}$; e) from 1-11 mol\% CuI, $4 \mathrm{~mol} \%$ [PdCl $\left.2\left(\mathrm{PPh}_{3}\right)_{2}\right], \mathrm{THF}$, reflux, $2 \mathrm{~d}$, $30 \%$ [61-64,67,68]; f) $\mathrm{S}_{2} \mathrm{Cl}_{2}, \mathrm{AlCl}_{3}, \mathrm{CH}_{2} \mathrm{Cl}_{2}$, reflux, $4 \mathrm{~h}, 67 \%$ [69]; g) $\mathrm{Zn}, \mathrm{HCl}_{\text {conc., }}$ glacial acetic acid (HOAc), ethyl acetate, reflux, $4 \mathrm{~h}, 81 \%$ [69]; h) $+8, \mathrm{~K}_{2} \mathrm{CO}_{3}, \mathrm{MeCN}$, reflux, $2 \mathrm{~d}, 79 \%$.

According to the literature, the synthesis of 1,7-bis(hydroxymethyl)-1,7-dicarba-closo-dodecaborane(12) (2) [66] was straightforward (Scheme 1, step b), and bromination of both hydroxyl groups was carried out following the procedure for the mono-substituted derivative 1-hydroxymethyl-1,7-dicarba- 
closo-dodecaborane(12) [65], giving 1,7-bis(bromomethyl)-1,7-dicarba-closo-dodecaborane(12) (3) in excellent yield (Scheme 1, step c) (analytical details are given in the electronic supporting information).

After the successful synthesis of $\mathbf{3}$ and $\mathbf{1}$, the following Kumada-like coupling reaction (Scheme 1, steps $\mathrm{d}$ or e) was carried out. The coupling of two carborane clusters via a methylene group with palladium catalysts has already been reported [68,69]; however, the tris-meta-carborane moiety 4 obtained here with a large boron content of 30 boron atoms per single molecule is new (Scheme 1).

After work-up, 4 was isolated in 30\% yield [56,62]. According to the proposed mechanism for the copper(I)-assisted Kumada coupling, some of the Grignard reagent is used to activate the palladium catalyst, and therefore, undergoes a homocoupling reaction, which can be the reason for low yields [62]. However, here, this reaction has only a marginal impact on the yield, and the major side products are the result of the incomplete conversion of 3 or the respective Grignard derivative. The observed side products after work-up, namely 1-(hydroxymethyl)-7-(1,7-dicarba-closo-dodecaboran-9-ylmethyl)-1,7-dicarba-closo-dodecaborane (SP1) and 1-methyl-7-(1,7-dicarba-closo-dodecaboran-9-ylmethyl)-1,7-dicarba-closo-dodecaborane) (SP2), confirm these assumptions (more information is given in the electronic supporting information).

The introduction of the thiol group at position 9 of the central carborane cluster in 4 was carried out using the procedure for unsubstituted ortho- and meta-carboranes (Scheme 1, steps $\mathrm{f}$ and g) [70]. Reduction of the disulfide 1,2-bis[1,7-bis(1,7-dicarba-closo-dodecaboran-9-ylmethyl)-1,7-dicarba-closo-dodecaboran-9-yl]disulfane (5) was straightforward following the given procedure [70], but the work-up after reduction of 5 to 1,7-bis(1,7-dicarba-closo-dodecaboran-9-ylmethyl)-1,7-dicarba-closo-dodecaboran-9-yl-thiol (6) was slightly modified. The disulfide 5 and the thiol $\mathbf{6}$ were isolated in good to very good yield.

A synthetic protocol which was developed for 9-mercapto-1,7-dicarba-closo-dodecaborane(12) was adapted to the reaction of thiol 6 (Figure 2) to give the final product 7 with an increased boron load (Scheme 1, step h) [45-47].
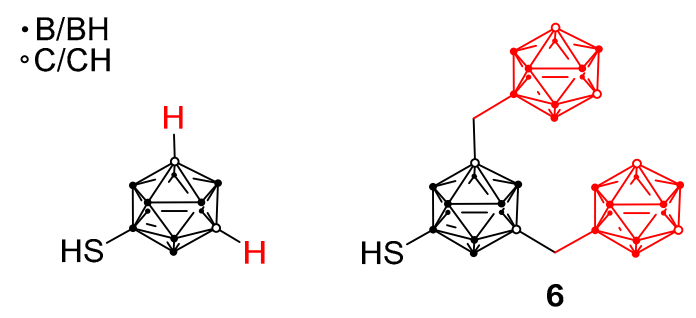

Figure 2. Comparison between 9-mercapto-1,7-dicarba-closo-dedecaboran(12) (left) and 1,7-bis(1,7-dicarba-closo-dodecaboran-9-ylmethyl)-1,7-dicarba-closo-dodecaboran-9-yl-thiol (6) (right) (altered fragments are drawn in red).

The s-triazinyl dichloride $\mathbf{8}$ was prepared according to the procedure described in our recent work [46,47]. Product 7 was obtained in very good yield; the overall yield about seven steps, starting from meta-carborane, including the synthesis of compound $\mathbf{1}$, is about $10 \%$.

All synthesized compounds were fully characterized by NMR and IR spectroscopy, mass spectrometry, elemental analysis and melting point determination. For 4 and 6, single crystals were obtained suitable for X-ray diffraction.

Although the appearance of compound 4 is quite simple, characterization was not trivial. Due to the large number of different boron atoms, the characterization of 4 via NMR was challenging. In the ${ }^{1} \mathrm{H}$ NMR spectrum, there are three significant signals observable. First, at $1.38 \mathrm{ppm}$ to $3.42 \mathrm{ppm}$ the typical "multiplet" (very broad signal appearing as a multiplet formed by overlapping of all BH proton signals) of the $\mathrm{BH}$ groups is observed ( 28 protons). Second, two very intense and broad singlets, with an integral of four protons each, were observed at $1.89 \mathrm{ppm}$ and $2.88 \mathrm{ppm}$. Considering the electron-withdrawing effect of the carborane moieties, the signal at $2.88 \mathrm{ppm}$ was assigned to the cluster $\mathrm{CH}$ groups and the signal at $1.89 \mathrm{ppm}$ to the methylene groups in 4 . This assumption was 
further corroborated by 2D-NMR (HSQC and HMBC) spectroscopy. In the ${ }^{13} \mathrm{C}$ NMR spectrum of compound 4 using the pulse sequence for an "attached proton test" experiment (APT), three signals were observed. The signal at $25.9 \mathrm{ppm}$ has a very broad appearance and can be assigned to the $\mathrm{CH}_{2}$ group; line broadening is caused by the connected boron atoms of the two terminal carborane clusters. The second signal at $54.0 \mathrm{ppm}$ can easily be identified as the cluster $\mathrm{CH}$ group. These observations were also confirmed by 2D-NMR experiments. The third signal at $76.1 \mathrm{ppm}$ is clearly identified by 2D-HMBC NMR as the quaternary carbon atoms in the central carborane cluster. The interpretation of the ${ }^{11} \mathrm{~B}$ NMR experiments was more difficult. Due to the magnetic inequivalence of the boron atoms in 4, many boron signals were observed in the NMR spectrum. Only the signal at $-1.9 \mathrm{ppm}$ could be directly interpreted as the boron atom at position 9 in both terminal carborane clusters based on the proton-coupled ${ }^{11} \mathrm{~B}$ NMR spectrum, where this signal is still observed as a singlet. Single crystals of 4 were obtained from ethyl acetate/ $n$-hexane solution. The molecular structure (Figure 3 ) confirms the spectroscopic assignments.

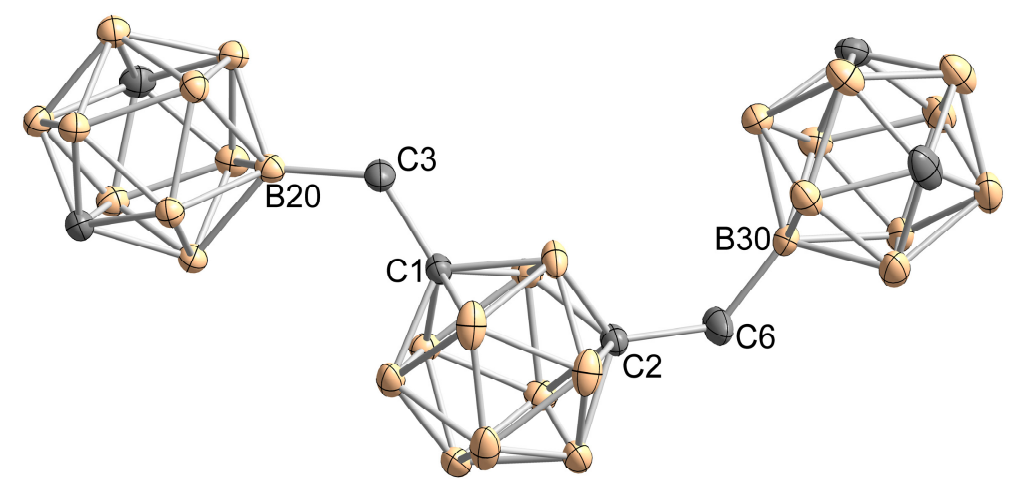

Figure 3. Molecular structure of 1,7-bis(1,7-dicarba-closo-dodecaboran-9-ylmethyl)-1,7-dicarba-closododecaborane (4). Hydrogen atoms are omitted for clarity. Thermal ellipsoids are drawn at the 50\% probability level. Selected bond lengths [pm] and bond angles [ $\left.{ }^{\circ}\right]$ : C1-C3 153.5(2), C3-B20 160.1(3), C2-C6 153.0(2), C6-B30 159.6(3); C1-C3-B20 123.0(2), C2-C6-B30 124.2(2).

Like 4, disulfide 1,2-bis[1,7-bis(1,7-dicarba-closo-dodecaboran-9-ylmethyl)-1,7-dicarba-closododecaboran-9-yl]disulfane (5) shows the typical signals in the ${ }^{1} \mathrm{H}$ NMR spectrum: $\mathrm{BH}$ protons in a range from $1.39 \mathrm{ppm}$ to $3.57 \mathrm{ppm}$ as a very broad multiplet, protons of the bridging methylene groups at 1.89 and $1.91 \mathrm{ppm}$, and the cluster $\mathrm{CH}$ groups at $2.89 \mathrm{ppm}$, all as broad singlets. All integrals in the ${ }^{1} \mathrm{H}$ NMR spectrum correspond to the respective atom numbers in the sum formula of 5 . The ${ }^{11} \mathrm{~B}$ NMR spectrum of compound $\mathbf{5}$ is more surprising. Three singlets are observed, indicating the presence of three different B-S groups. Apparently, compound $\mathbf{5}$ is readily oxidized under ambient conditions, as mass spectrometry indicated the formation of the mono-oxidized derivative S-[1,7-bis(1,7-dicarba-closo-dodecaboran-9-ylmethyl)-1,7-dicarba-closo-dodecaboran-9-yl]-1,7-bis(1,7dicarba-closo-dodecaboran-9-ylmethyl)-1,7-dicarba-closo-dodecaborane-9-sulfinthioate $\quad\left(5^{\prime}\right) \quad$ (see experimental section). Unsymmetrical oxidized disulfides are already known [71].

This observation explains the presence of the three different $B-S$ groups in the ${ }^{11} \mathrm{~B} N M R$ spectrum: The disulfide 5 exhibits one signal and the unsymmetrical thiosulfinate $\mathbf{5}^{\prime}$ (Figure 4 ) two (1:1 mixture of $\mathbf{5}$ and $\mathbf{5}^{\prime}$ ). All other boron atoms in $\mathbf{5}$ and $\mathbf{5}^{\prime}$ are observed as a mixture of overlapping multiplets and singlets, which do not allow further assignment. Fortunately, the presence of this oxidized species besides 5 is no problem for the synthesis of $\mathbf{6}$, as the disulfide is cleaved under reductive conditions, which also reduce the oxidized species $5^{\prime}$. 


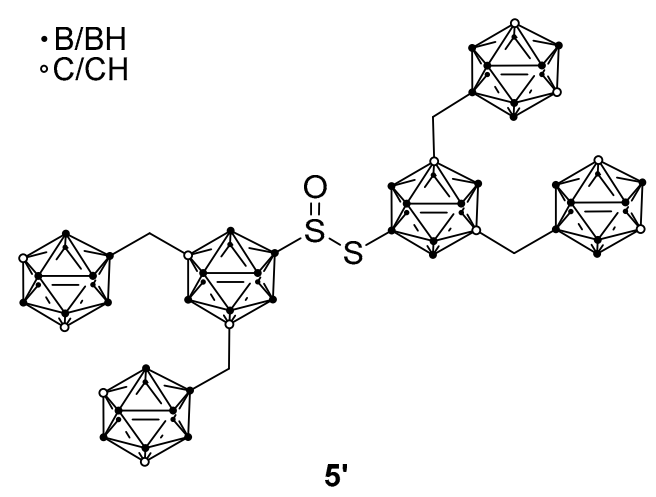

Figure 4. Mono-oxidized derivative of 1,2-bis[1,7-bis(1,7-dicarba-closo-dodecaboran-9-ylmethyl)-1,7dicarba-closo-dodecaboran-9-yl]disulfane $\left(5^{\prime}\right)$.

As expected, the spectroscopic data of 1,7-bis(1,7-dicarba-closo-dodecaboran-9-ylmethyl)-1,7dicarba-closo-dodecaboran-9-yl-thiol (6) are similar to 4 . In addition to the proton signals of the $\mathrm{CH}$ and $\mathrm{BH}$ groups of the carborane clusters and the $\mathrm{CH}_{2}$ signals for the bridging methylene groups, a multiplet at $0.39 \mathrm{ppm}$ is observed for the thiol group in 6, comparable with 9-mercapto-1,7-dicarba-closo-dodecaborane(12) [70]. The molecular structure of 6 is shown in Figure 5.

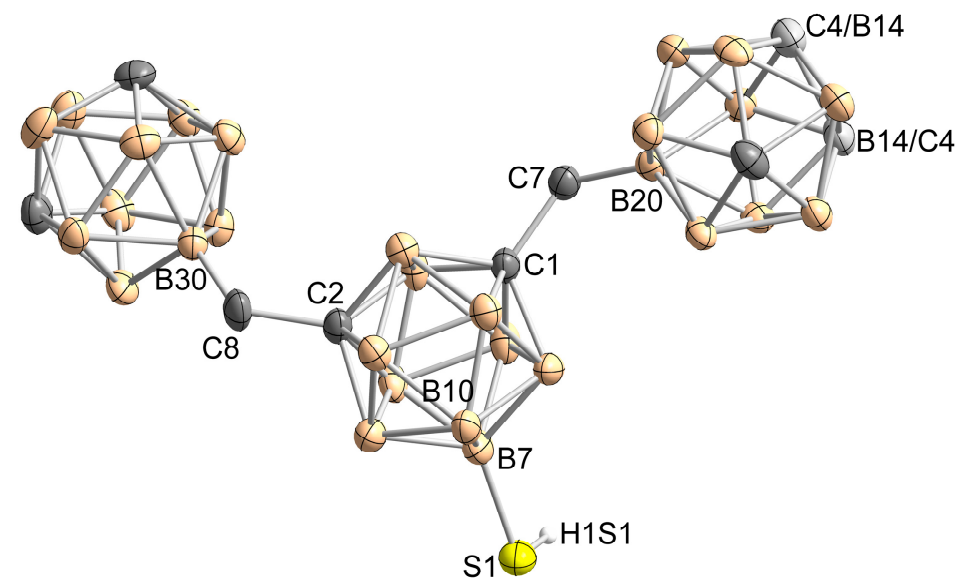

Figure 5. Molecular structure of 1,7-bis(1,7-dicarba-closo-dodecaboran-9-ylmethyl)-1,7-dicarba-closododecaboran-9-ylthiol (6). Thermal ellipsoids are drawn at the 50\% probability level. Carbon/boron disorder in one of the carborane clusters in a ratio of 0.55(2):0.45(2) (shown) and the central carborane unit (ratio of 0.938(1):0.062(1), not shown) is observed. Hydrogen atoms (other than SH) are omitted for clarity. Selected bond lengths [pm] and bond angles [ [ ${ }^{\circ}$ : S1-B7 187.0(4), C1-C7 152.9(3), C7-B20 159.9(4), C2-C8 152.5(4), C8-B30 160.3(4); C1-C7-B20 122.7(2), C2-C8-B30 124.2(2).

Compound 7 showed the expected signals in the ${ }^{1} \mathrm{H}$ NMR spectrum, including a broad multiplet from 1.5 to $3.5 \mathrm{ppm}$ corresponding to $54 \mathrm{BH}$ groups. Furthermore, all expected signals were observed in the ${ }^{13} \mathrm{C},{ }^{11} \mathrm{~B}$ and ${ }^{11} \mathrm{~B}\left\{{ }^{1} \mathrm{H}\right\}$ NMR spectra. High-resolution electrospray-ionization mass spectrometry showed the signal for protonated $7\left([7+\mathrm{H}]^{+}\right.$, calculated $m / z$ 1427.3121, obtained $\left.m / z 1427.3109\right)$ (Figure 6) with an impressive isotopic pattern. 

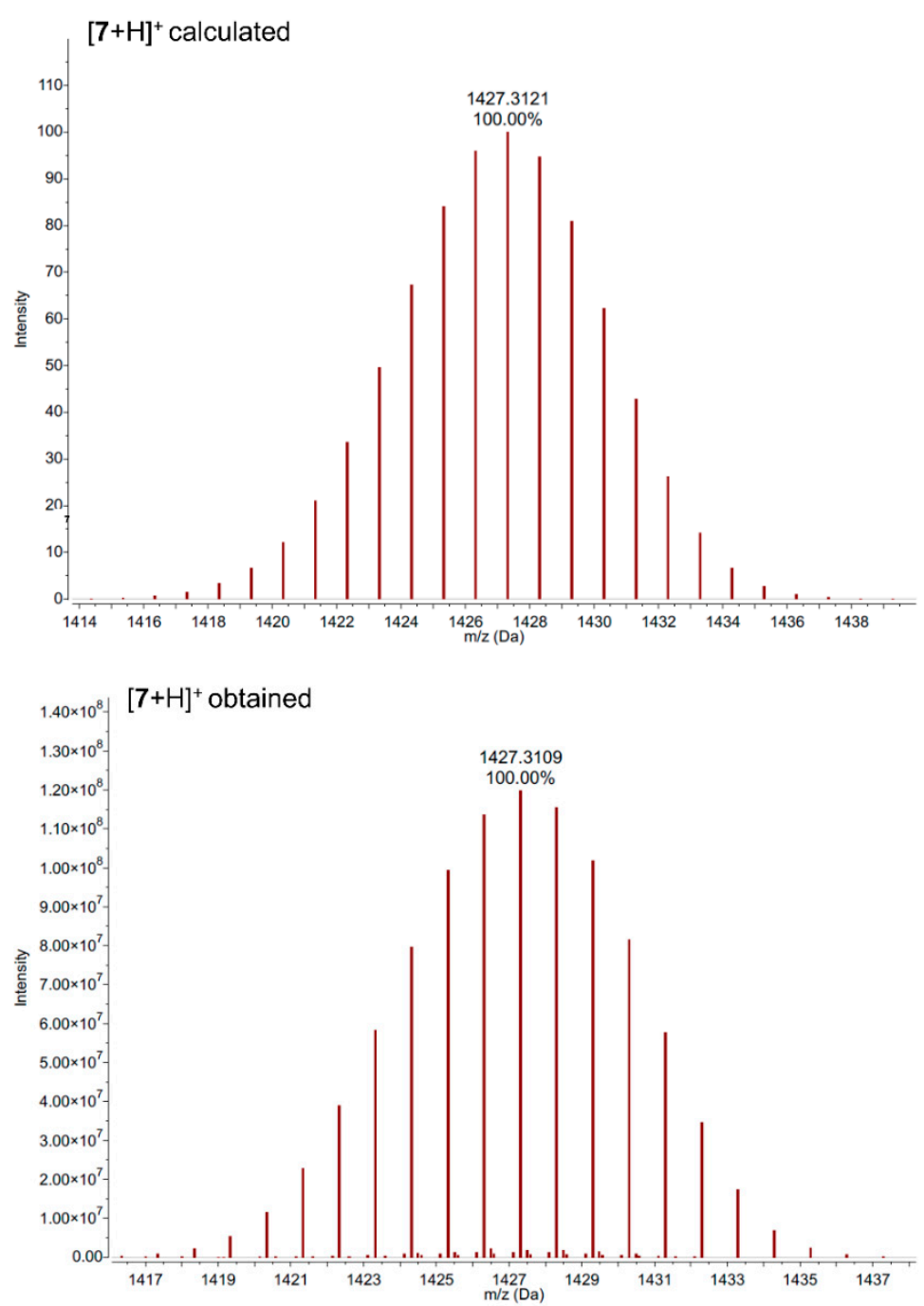

Figure 6. Comparison of the isotopic pattern of the calculated (top) and measured signal (bottom) of $[7+\mathrm{H}]^{+}[41]$.

\section{Materials and Methods}

Materials and methods: All reactions were carried out under nitrogen atmosphere using Schlenk techniques, if not reported otherwise. Anhydrous diethyl ether and dichloromethane were obtained with an MBRAUN solvent purification system MB SPS- 800 . Acetonitrile, benzene and 2,4,6-collidine were dried over $\mathrm{CaH}_{2}$ and distilled. Anhydrous tetrahydrofuran was dried over potassium and distilled. All solvents were stored over molecular sieves (3 $\AA$ ) under nitrogen atmosphere. 9-Iodo-1,7-dicarba-closo-dodecaborane(12) (1) [62-64], 1,7-bis(hydroxymethyl)-1,7-dicarba-closo-dodecaborane(12) (2) [66], 1,7-bis(bromomethyl)-1,7-dicarba-closo-dodecaborane(12) (3) [65], and tert-butyl- $N$-(4,6-dichloro-1,3,5triazin-2-yl)- $N-\left(1^{\prime}, 2^{\prime}: 3^{\prime}, 4^{\prime}\right.$-di-O-isopropylidene-6' -deoxy- $\alpha$-D-galactopyranos-6'-yl)glycinate (8) [46,47] were prepared according to the literature. All other chemicals were purchased and used as received.

Thin-layer chromatography (TLC) with silica gel $60 \mathrm{~F}_{254}$ on glass available from Merck KGaA was used for monitoring the reactions. Carborane-containing spots were visualized with a $5-10 \%$ solution of $\mathrm{PdCl}_{2}$ in methanol. For chromatography, silica gel (60 ̊) with a particle diameter in the range of 0.035 to $0.070 \mathrm{~mm}$, the Biotage ${ }^{\circledR}$ Isolera 1 or the Biotage ${ }^{\circledR}$ Isolera 4 automatic purification system with SNAP (particle diameter in the range of 0.040 to $0.065 \mathrm{~mm}$ ) and SNAP Ultra (spherical particles, diameter $0.025 \mathrm{~mm}$ ) cartridges were used. The triazine and carborane species were detected by an integrated UV/Vis detector (Isolera 1) or evaporative light scattering detector (ELSD) A-120 
(Isolera 4). For chromatography, solvents were distilled before use. NMR measurements were carried out on a Bruker AVANCE III HD spectrometer with an Ascend ${ }^{\mathrm{TM}} 400$ magnet at room temperature. Tetramethylsilane was used as internal standard for ${ }^{1} \mathrm{H}$ and ${ }^{13} \mathrm{C}\left\{{ }^{1} \mathrm{H}\right\}$ NMR spectra, and ${ }^{11} \mathrm{~B}$ and ${ }^{11} \mathrm{~B}\left\{{ }^{1} \mathrm{H}\right\}$ NMR spectra were referenced to the $\Xi$ scale [72]. NMR spectra were recorded at the following frequencies: ${ }^{1} \mathrm{H}-400.16 \mathrm{MHz},{ }^{13} \mathrm{C}-100.63 \mathrm{MHz},{ }^{11} \mathrm{~B}-128.38 \mathrm{MHz}$. All chemical shifts are reported in parts per million (ppm). Assignment of the ${ }^{1} \mathrm{H}$ and ${ }^{13} \mathrm{C}$ signals was based on 2D NMR spectra (H,H-COSY, HSQC, HMQC, HMBC). Identification of the boron atom attached to sulfur was possible by comparison of the proton-coupled and -decoupled ${ }^{11} \mathrm{~B}$ NMR spectra. NMR data were interpreted with MestReNova [73]. NMR signals that appear as broad overlapping signals with the shape of a multiplet in either ${ }^{1} \mathrm{H},{ }^{11} \mathrm{~B}\left\{{ }^{1} \mathrm{H}\right\}$ or ${ }^{11} \mathrm{~B}$ NMR spectra are described as 'br' (broad). In this case, the superscript $a$ is added $\left(b^{a}\right)$. The numbering scheme of compound 7 for assignments of NMR signals is given at the end of the experimental section (Figure 7). IR data were obtained with a PerkinElmer FT-IR spectrometer Spectrum 2000 as KBr pellets and on a Thermo Scientific Nicolet iS5 with an ATR unit in the range of 4000 to $400 \mathrm{~cm}^{-1}$. Electrospray ionization mass spectrometry was performed with an ESI ESQUIRE 3000 PLUS spectrometer with an IonTrap-analyzer from Bruker Daltonics or on a MicroTOF spectrometer from Bruker Daltonics with a ToF analyzer in negative or positive mode. Dichloromethane, acetonitrile, methanol, or mixtures of these solvents, were used as solvents for the measurements. Electron impact mass spectrometry was performed with a MAT 8230 spectrometer with a sector field analyzer from Thermo Scientific. Elemental analysis was conducted with a VARIO EL elemental analyzer from Heraeus. Melting points were determined with a Gallenkamp MPD350.BM2.5 melting point device and are not corrected.

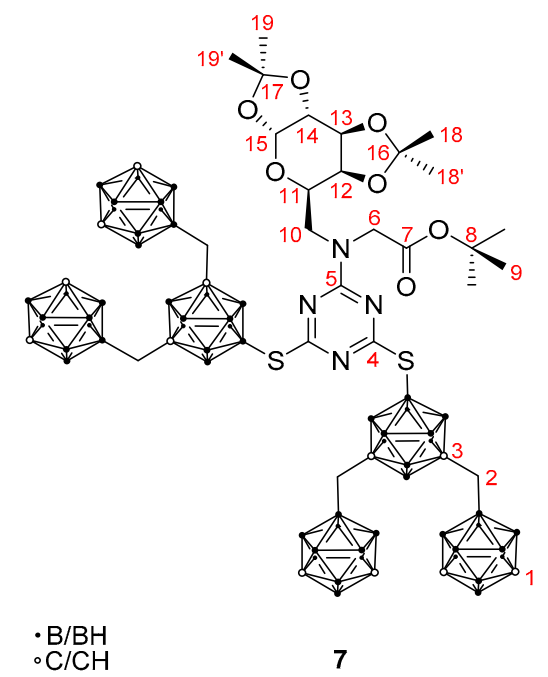

Figure 7. Numbering scheme of compound 7.

X-ray diffraction experiments: Measurements were performed with a Gemini diffractometer (Rigaku Oxford Diffraction) with Mo-K $\mathrm{K}_{\alpha}$ radiation $(\lambda=71.073 \mathrm{pm}), \omega$-scan rotation. Data reduction was performed with CrysAlis Pro [74], including the program SCALE3 ABSPACK [75] for empirical absorption correction. The structures were solved by dual space methods (SHELXT-2014) [76] and the refinement of all non-hydrogen atoms was performed with SHELXL-2018 [77]. For 6, H atoms (except $\mathrm{SH}$ ) were calculated on idealized positions. In all other cases, $\mathrm{H}$ atoms were located on difference Fourier maps calculated at the final stage of the structure refinement. Structure figures were generated with Diamond [78]. The electronic supporting information and CCDC 1945754 (4), 1945755 (6), 1945756 (SP1) and 1945757 (SP2) contain the supplementary crystallographic data for this paper. The crystallographic data can be obtained free of charge via www.ccdc.cam.ac.uk/conts/retrieving.html (or from the Cambridge Crystallographic Data Centre, 12 Union Road, Cambridge CB2 1EZ, UK; fax: (+44)1223-336-033; or deposit@ccdc.cam.uk). 
1,7-Bis(1,7-dicarba-closo-dodecaboran-9-ylmethyl)-1,7-dicarba-closo-dodecaborane (4): A $250 \mathrm{~mL}$ two-necked round bottom flask equipped with a condenser and a dropping funnel was charged with $6.97 \mathrm{~g}$ (287 mmol, 30.1 eq.) Mg turnings, evacuated and purged with nitrogen. The Mg turnings were activated by mechanical stirring and suspended in $10 \mathrm{~mL}$ dry tetrahydrofuran. A second Schlenk flask was charged with $3.14 \mathrm{~g}$ (9.52 mmol, 1.00 eq.) 1,7-bis(bromomethyl)-1,7-dicarba-closo-dodecaborane(12) (3) and $80 \mathrm{~mL}$ dry tetrahydrofuran. The carborane solution was transferred into the dropping funnel and slowly added to the Mg turnings. The reaction mixture was stirred under reflux conditions for $2 \mathrm{~h}$. A $250 \mathrm{~mL}$ two-necked round bottom flask with a condenser and a dropping funnel was evacuated and purged with nitrogen, and $3.00 \mathrm{~g}$ (17.6 mmol, 1.85 eq.) 9-iodo-1,7-dicarba-closo-dodecaborane(12) (1) were added and dissolved in $60 \mathrm{~mL}$ dry tetrahydrofuran. The mixture was cooled to $0{ }^{\circ} \mathrm{C}$. The Grignard reagent from the first reaction step was filtered, transferred into the second dropping funnel and slowly added to 9 -iodo- $m$-carborane $(\mathbf{1})$ at $0{ }^{\circ} \mathrm{C}$. The mixture was stirred for $30 \mathrm{~min}$ at room temperature. Subsequently, $0.34 \mathrm{~g}$ (1.79 mmol, 0.19 eq.) copper(I) iodide and $0.78 \mathrm{~g}(1.11 \mathrm{mmol}, 0.12$ eq.) bis(triphenylphosphine)palladium(II) dichloride were added and the mixture was stirred under reflux for $2 \mathrm{~d}$. The reaction was stopped by adding $30 \mathrm{~mL}$ saturated $\mathrm{NaCl}$ solution and $15 \mathrm{~mL} 2 \mathrm{M}$ hydrochloric acid. The aqueous layer was separated from the organic one and extracted three times each with $30 \mathrm{~mL}$ ethyl acetate. The combined organic layers were dried over $\mathrm{MgSO}_{4}$, filtered and the solvent was removed under reduced pressure. The raw product was purified by column chromatography ( $n$-hexane/ethyl acetate, 10:1, $v / v)$ and $1.32 \mathrm{~g}\left(2.89 \mathrm{mmol}, 30 \%, \mathrm{R}_{f}=0.42\right)$ of compound 4 were isolated as a colorless solid. 1-Methyl-7-(1,7-dicarba-closo-dodecaboran-9-ylmethyl)-1,7-dicarba-closo-dodecaborane (SP2) was obtained in 18\% yield (529 mg, $1.68 \mathrm{mmol}, \mathrm{R}_{f}=0.58,10: 1, n$-hexane/ethyl acetate, $\left.v / v\right)$ and 1-(hydroxymethyl)-7-(1,7-dicarba-closo-dodecaboran-9-ylmethyl)-1,7-dicarba-closo-dodecaborane (SP1) was obtained in $8 \%$ yield ( $252 \mathrm{mg}, 762 \mu \mathrm{mol}, \mathrm{R}_{f}=0.31,10: 1, n$-hexane/ethyl acetate, $v / v$ ) (additional analytical data are given in the supplementary information). Colorless crystals of 4 suitable for X-ray structure determination were obtained from $\mathrm{CHCl}_{3}$ at room temperature. Crystallographic data are given in Table S4, and the molecular structure is depicted in Figure $3 . \mathrm{T}_{\mathrm{m}}: 182-185{ }^{\circ} \mathrm{C}$ (acetone). IR (KBr): $\tilde{v}=3420$ (w, H bridges), $3060\left(\mathrm{~s}, v \mathrm{C}_{\mathrm{sp} 2} \mathrm{H}\right), 2926\left(\mathrm{w}, v_{\mathrm{sp} 3} \mathrm{H}\right), 2906\left(\mathrm{w}, v \mathrm{C}_{\mathrm{sp} 3} \mathrm{H}\right), 2601(\mathrm{~s}, v B \mathrm{H})$, $1733(\mathrm{w}), 1418\left(\mathrm{~m}, \delta \mathrm{CH}_{2}\right), 1291(\mathrm{w}), 1249(\mathrm{w}), 1184(\mathrm{w}), 1159(\mathrm{~m}), 1105(\mathrm{w}), 1068(\mathrm{~m}), 1009(\mathrm{~m}), 980(\mathrm{~m})$, $923(\mathrm{w}), 851(\mathrm{w}), 831(\mathrm{w}), 811(\mathrm{w}), 724\left(\mathrm{~m}, \mathrm{CH}_{2}\right.$ rocking), $683(\mathrm{w}), 538(\mathrm{w}), 519(\mathrm{w}) \mathrm{cm}^{-1}$. ${ }^{1} \mathrm{H} \mathrm{NMR}$ $\left(\mathrm{CDCl}_{3}\right): \delta=1.38-3.42\left(\mathrm{~m}, \mathrm{vbr}, 28 \mathrm{H}, 2 \mathrm{xB}_{10} \mathrm{H}_{9}, 1 \mathrm{xB}_{10} \mathrm{H}_{10}\right), 1.89\left(\mathrm{~s}, \mathrm{br}, 4 \mathrm{H}, 2 \mathrm{xCH}_{2}\right), 2.88 \mathrm{ppm}(\mathrm{s}, \mathrm{br}, 4 \mathrm{H}$, $\left.4 \times \mathrm{CH}_{\text {Cluster }}\right) .{ }^{13} \mathrm{C}\left\{{ }^{1} \mathrm{H}\right\} \mathrm{NMR}\left(\mathrm{CDCl}_{3}\right): \delta=25.9\left(\mathrm{~s}, \mathrm{vbr}, \mathrm{CH}_{2}, 2 \times \mathrm{CH}_{2}\right), 54.0\left(\mathrm{~s}, \mathrm{br}, \mathrm{CH}, 4 \times \mathrm{CH}_{\mathrm{Cluster}}\right), 76.1$ $\operatorname{ppm}\left(\mathrm{s}, \mathrm{br}, \mathrm{C}_{\mathrm{q}}, \mathrm{C}_{\mathrm{q}, \text { Cluster }) .}{ }^{11} \mathrm{~B}\left\{{ }^{1} \mathrm{H}\right\} \operatorname{NMR}\left(\mathrm{CDCl}_{3}\right): \delta=-20.3\right.$ to $-16.3(\mathrm{~m}, \mathrm{br}, 4 \mathrm{~B}),-14.1(\mathrm{~s}, 4 \mathrm{~B}),-13.1$ (s, $4 \mathrm{~B}),-12.5$ to $-8.8(\mathrm{~m}, \mathrm{br}, 10 \mathrm{~B}),-6.1(\mathrm{~m}, 6 \mathrm{~B}),-1.9 \mathrm{ppm}(\mathrm{s}, 2 \mathrm{~B}, \mathrm{BC}) .{ }^{11} \mathrm{~B} \mathrm{NMR}\left(\mathrm{CDCl}_{3}\right): \delta=-21.0$ to -16.3 (m, br, 4 B), -15.6 to -8.6 (m, br, 18 B), -8.1 to -4.3 (m, $6 \mathrm{~B}),-1.9$ ppm (s, $2 \mathrm{~B}, \mathrm{BC})$. LRMS (EI): $\mathrm{C}_{8} \mathrm{H}_{36} \mathrm{~B}_{30}, m / z$ calcd: $456.6\left([\mathrm{M}]^{+}\right)$; found: 456.6 .

1,2-Bis[1,7-bis(1,7-dicarba-closo-dodecaboran-9-ylmethyl)-1,7-dicarba-closo-dodecaboran-9-yl]disulfane (5): A $100 \mathrm{~mL}$ two-necked round bottom flask, equipped with a condenser, was charged with $0.51 \mathrm{~g}(1.12$ mmol, 1.00 eq.) 1,7-bis(1,7-dicarba-closo-dodecaboran-9-ylmethyl)-1,7-dicarba-closo-dodecaborane (4) and $0.19 \mathrm{~g}$ (1.42 mmol, 1.27 eq.) anhydrous $\mathrm{AlCl}_{3}$. The starting materials were suspended in $50 \mathrm{~mL}$ anhydrous $\mathrm{CH}_{2} \mathrm{Cl}_{2}$ and cooled to $0^{\circ} \mathrm{C} .0 .05 \mathrm{~mL}$ (0.08 g, $0.63 \mathrm{mmol}, 0.56$ eq.) $\mathrm{S}_{2} \mathrm{Cl}_{2}$ dissolved in $2 \mathrm{~mL}$ anhydrous $\mathrm{CH}_{2} \mathrm{Cl}_{2}$ were added slowly to this mixture. The reaction mixture was stirred for $4 \mathrm{~h}$ under reflux. The reaction was stopped by pouring the mixture onto crushed ice. The resulting aqueous layer was extracted three times each with $30 \mathrm{~mL} \mathrm{CH}_{2} \mathrm{Cl}_{2}$. The combined organic layers were washed once with $30 \mathrm{~mL}$ distilled $\mathrm{H}_{2} \mathrm{O}$, dried over $\mathrm{MgSO}_{4}$, filtered off and the solvent was removed under reduced pressure. The raw product was purified by column chromatography using the Isolera Four device (SNAP Ultra $25 \mathrm{~g}$ cartridge, $12 \mathrm{~mL} / \mathrm{min}, n$-hexane/ethyl acetate 49:1 to 41:9, v/v). $0.41 \mathrm{~g}(0.42$ mmol, $67 \%$ ) of compound 5 were isolated as an off-white crystalline solid. During characterization of 5, partial oxidization occurred. $\mathrm{T}_{\mathrm{m}}: 109-112{ }^{\circ} \mathrm{C}$ (ethyl acetate). IR (KBr): $\tilde{v}=3432$ (w, H bridges), 3059 $\left(\mathrm{m}, v \mathrm{C}_{\mathrm{sp} 2} \mathrm{H}\right), 2925\left(\mathrm{~m}, v \mathrm{C}_{\mathrm{sp} 3} \mathrm{H}\right), 2907\left(\mathrm{~m}, v_{\mathrm{sp} 3} \mathrm{H}\right), 2597(\mathrm{~s}, v \mathrm{BH}), 1710(\mathrm{w}), 1684(\mathrm{~m}), 1616(\mathrm{~m}), 1443(\mathrm{w}$, $\left.\delta \mathrm{CH}_{2}\right), 1419\left(\mathrm{~m}, \delta \mathrm{CH}_{2}\right), 1378(\mathrm{w}), 1356(\mathrm{w}), 1288(\mathrm{w}), 1220(\mathrm{w}), 1159(\mathrm{~m}), 1106(\mathrm{w}), 1068(\mathrm{~m}), 1012(\mathrm{~s}$, 
vBS), $980(\mathrm{~m}), 960(\mathrm{~m}), 923(\mathrm{w}), 897(\mathrm{w}), 847(\mathrm{~m}), 723\left(\mathrm{~s}, \mathrm{CH}_{2}\right.$ rocking), $620(\mathrm{w}), 587(\mathrm{w}), 534(\mathrm{w}), 517(\mathrm{w})$, $485(\mathrm{w}) \mathrm{cm}^{-1}$. ${ }^{1} \mathrm{H}$ NMR $\left(\mathrm{CDCl}_{3}\right): \delta=1.39-3.57\left(\mathrm{~m}, \mathrm{vbr}, 54 \mathrm{H}, 6 \mathrm{xB}_{10} \mathrm{H}_{9}\right), 1.89,1.91\left(\mathrm{~s}, \mathrm{br}, 8 \mathrm{H}, 4 \times \mathrm{CH}_{2}\right)$, 2.89 ppm (s, br, $\left.8 \mathrm{H}, 8 \times \mathrm{CH}_{\mathrm{Cluster}}\right) .{ }^{13} \mathrm{C}\left\{{ }^{1} \mathrm{H}\right\} \mathrm{NMR}\left(\mathrm{CDCl}_{3}\right): \delta=26.3\left(\mathrm{~s}, \mathrm{vbr}, \mathrm{CH}_{2}, 4 \times \mathrm{CH}_{2}\right), 54.1$ (s, br, $\left.\mathrm{CH}, 8 \mathrm{xCH}_{\text {Cluster }}\right), 74.9,75.4,75.6 \mathrm{ppm}\left(\mathrm{s}, \mathrm{C}_{\mathrm{q}}, 4 \times \mathrm{C}_{\mathrm{q}, \text { Cluster }}\right) .{ }^{11} \mathrm{~B}\left\{{ }^{1} \mathrm{H}\right\} \mathrm{NMR}\left(\mathrm{CDCl}_{3}\right): \delta=-19.3(\mathrm{~s}, \mathrm{br}, 4 \mathrm{~B})$, -17.5 (s, 4 B), -14.0 (s, 8 B), -13.1 (s, 8 B), -10.8 (s, br, 6 B), -9.7 (s, br, 12 B), -6.1 (s, br, 12 B), -2.1 (s, $4 \mathrm{~B}, \mathrm{BC}),-0.4,0.2,0.5 \mathrm{ppm}\left(\mathrm{s}, \mathrm{BS} / \mathrm{BS}\right.$ and BS/BS(O)). ${ }^{11} \mathrm{~B} \mathrm{NMR}\left(\mathrm{CDCl}_{3}\right): \delta=-18.5(\mathrm{~m}, \mathrm{br}, 8 \mathrm{~B}),-13.5$ $(\mathrm{m}, 16 \mathrm{~B}),-10.4(\mathrm{~m}, \mathrm{br}, 18 \mathrm{~B}),-6.1\left(\mathrm{~d}, \mathrm{br},{ }^{1} J_{\mathrm{BH}}=163 \mathrm{~Hz}, 12 \mathrm{~B}\right),-2.1(\mathrm{~s}, 4 \mathrm{~B}, \mathrm{BC}),-0.4,0.2,0.5 \mathrm{ppm}(\mathrm{s}$, BS/BS and BS/BS(O)). HRMS (ESI+): $\mathrm{C}_{16} \mathrm{H}_{70} \mathrm{~B}_{60} \mathrm{OS}_{2}, \mathrm{~m} / z$ calcd: $993.0939\left(\left[\mathrm{M}_{\mathrm{ox}}+\mathrm{H}\right]^{+}\right)$; found: 993.0937; (ESI-): $\mathrm{C}_{16} \mathrm{H}_{70} \mathrm{~B}_{60} \mathrm{~S}_{2}, \mathrm{~m} / z$ calcd: 1011.0619 ([M $\left.\left.+\mathrm{Cl}\right]^{-}\right)$; found: $1011.0673 .{ }^{11} \mathrm{~B} \mathrm{NMR}$ spectroscopy and mass spectrometry indicate the presence of the oxidized derivative $\mathbf{5}^{\prime}$. Fortunately, the presence of this oxidized species besides 5 is no problem for the synthesis of $\mathbf{6}$, as the disulfane is cleaved under reductive conditions, which also reduce the oxidized species $\mathbf{5}^{\prime}$.

1,7-Bis(1,7-dicarba-closo-dodecaboran-9-ylmethyl)-1,7-dicarba-closo-dodecaboran-9-yl-thiol (6): A $100 \mathrm{~mL}$ round bottom flask, equipped with a condenser, was charged with $0.20 \mathrm{~g}$ (0.21 mmol, 1.00 eq.) 1,2-bis[1,7-bis(1,7-dicarba-closo-dodecaboran-9-ylmethyl)-1,7-dicarba-closo-dodecaboran-9-yl]disulfane (5) and $20 \mathrm{~mL}$ of a 1:1 mixture of concentrated hydrochloric acid and glacial acetic acid, as well as 10 $\mathrm{mL}$ ethyl acetate were added for a better solubility. The mixture was heated to reflux for $4 \mathrm{~h}$ and excess of zinc powder $(1.10 \mathrm{~g}, 16.8 \mathrm{mmol}, 80.0 \mathrm{eq}$.) was added in 12 portions. The mixture was cooled to room temperature and the acid neutralized with $\mathrm{Na}_{2} \mathrm{CO}_{3}$ and $\mathrm{NaHCO}_{3}$. The resulting aqueous layer was extracted three times each with $30 \mathrm{~mL} \mathrm{CH}_{2} \mathrm{Cl}_{2}$. The combined organic layers were washed once with distilled $\mathrm{H}_{2} \mathrm{O}$, dried over $\mathrm{MgSO}_{4}$, filtered and the solvent was removed under reduced pressure. The raw product was purified by column chromatography (n-hexane/ethyl acetate, 7:1 to 3:1, v/v) and 83 $\mathrm{mg}(0.17 \mathrm{mmol}, 81 \%)$ of compound 6 were isolated as an off-white solid. Colorless crystals of 6 suitable for X-ray structure determination were obtained from $\mathrm{CHCl}_{3}$ at room temperature. Crystallographic data are given in Table S4, and the molecular structure is depicted in Figure 5. $\mathrm{T}_{\mathrm{m}}: 180-183{ }^{\circ} \mathrm{C}$ (toluene). IR (KBr): $\tilde{v}=3416\left(\mathrm{w}, \mathrm{H}\right.$ bridges), $3055\left(\mathrm{~m}, v \mathrm{C}_{\mathrm{sp} 2} \mathrm{H}\right), 3031\left(\mathrm{~s}, v \mathrm{C}_{\mathrm{sp} 2} \mathrm{H}\right), 2923\left(\mathrm{~m}, v \mathrm{C}_{\mathrm{sp} 3} \mathrm{H}\right), 2907$ $\left(\mathrm{m}, v \mathrm{C}_{\mathrm{sp} 3} \mathrm{H}\right), 2850(\mathrm{~m}, v \mathrm{SH}), 2599(\mathrm{~s}, v \mathrm{BH}), 1466\left(\mathrm{w}, \delta \mathrm{CH}_{2}\right), 1418\left(\mathrm{~m}, \delta \mathrm{CH}_{2}\right), 1289(\mathrm{w}), 1159(\mathrm{~m}), 1108$ (w), $1068(\mathrm{~m}), 1011(\mathrm{~s}, v B S), 980(\mathrm{~m}), 962(\mathrm{~m}), 924(\mathrm{w}), 893(\mathrm{w}), 851(\mathrm{~m}), 776(\mathrm{w}), 759(\mathrm{w}), 722(\mathrm{~m}), 689$ $(\mathrm{w}), 664(\mathrm{w}), 588(\mathrm{w}), 517(\mathrm{w}), 437(\mathrm{w}) \mathrm{cm}^{-1} .{ }^{1} \mathrm{H} \mathrm{NMR}\left(\mathrm{CDCl}_{3}\right): \delta=0.39(\mathrm{~m}, 1 \mathrm{H}, \mathrm{SH}), 1.39-3.75(\mathrm{~m}, \mathrm{vbr}$, $\left.27 \mathrm{H}, 3 \mathrm{xB}_{10} \mathrm{H}_{9}\right), 1.89$ (s, br, $\left.4 \mathrm{H}, 2 \times \mathrm{CH}_{2}\right), 2.89 \mathrm{ppm}\left(\mathrm{s}, \mathrm{br}, 4 \mathrm{H}, 4 \times \mathrm{CH}_{\mathrm{Cluster}}\right) .{ }^{13} \mathrm{C}\left\{{ }^{1} \mathrm{H}\right\} \mathrm{NMR}\left(\mathrm{CDCl}_{3}\right): \delta=$ 26.0 (s, vbr, $\mathrm{CH}_{2}, 2 \times \mathrm{CH}_{2}$ ), 53.3, 55.1 (s, br, $\left.\mathrm{CH}, 4 \times \mathrm{CH}_{\mathrm{Cluster}}\right), 76.0 \mathrm{ppm}\left(\mathrm{s}, \mathrm{br}, \mathrm{C}_{\mathrm{q}}, 2 \mathrm{xC}\right.$, Cluster $) .{ }^{11} \mathrm{~B}\left\{{ }^{1} \mathrm{H}\right\}$ $\operatorname{NMR}\left(\mathrm{CDCl}_{3}\right): \delta=-19.3(\mathrm{~s}, \mathrm{br}, 2 \mathrm{~B}),-17.6(\mathrm{~s}, 2 \mathrm{~B}),-14.0(\mathrm{~s}, 4 \mathrm{~B}),-13.2(\mathrm{~s}, 4 \mathrm{~B}),-11.0(\mathrm{~s}, \mathrm{br}, 3 \mathrm{~B}),-9.8$ (s, br, 6 B), -6.1 (s, br, 6 B), -3.4 (s, 1 B, BS), -2.1 ppm (s, 2 B, BC). ${ }^{11} \mathrm{~B} \mathrm{NMR}\left(\mathrm{CDCl}_{3}\right): \delta=-18.7(\mathrm{~m}, \mathrm{br}, 4 \mathrm{~B})$, $-13.5(\mathrm{~m}, 8 \mathrm{~B}),-10.4(\mathrm{~m}, \mathrm{br}, 9 \mathrm{~B}),-6.1\left(\mathrm{~d}, \mathrm{br},{ }^{1} J_{\mathrm{BH}}=162 \mathrm{~Hz}, 6 \mathrm{~B}\right),-3.4(\mathrm{~s}, 1 \mathrm{~B}, \mathrm{BS}),-2.1 \mathrm{ppm}(\mathrm{s}, 2 \mathrm{~B}, \mathrm{BC})$. HRMS (ESI-): $\mathrm{C}_{8} \mathrm{H}_{36} \mathrm{~B}_{30} \mathrm{~S}, \mathrm{~m} / z$ calcd: 487.5469 ([M - H] $\left.]^{-}\right)$; found: 487.5438.

tert-Butyl-N-\{4,6-bis[(1,7-dicarba-closo-dodecaboran-9-ylmethyl)1,7-dicarba-closo-dodecaboran-9-ylthio]-1,3,

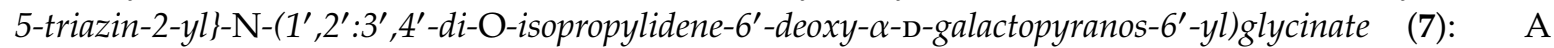
$100 \mathrm{~mL}$ round bottom flask, equipped with a condenser, was charged with $97 \mathrm{mg}(0.19 \mu \mathrm{mol}$, 1.00 eq.) tert-butyl-N-(4,6-dichloro-1,3,5-triazin-2-yl)- $N-\left(1^{\prime}, 2^{\prime}: 3^{\prime}, 4^{\prime}\right.$-di-O-isopropylidene-6' -deoxy- $\alpha$-Dgalactopyranos-6'-yl)glycinate (8), 290 mg (0.59 $\mu \mathrm{mol}, 3.12$ eq.) 1,7-bis(1,7-dicarba-closo-dodecaboran9-ylmethyl)-1,7-dicarba-closo-dodecaboran-9-ylthiol (6) and $133 \mathrm{mg}\left(0.96 \mu \mathrm{mol}, 5.06\right.$ eq.) $\mathrm{K}_{2} \mathrm{CO}_{3}$. This mixture was suspended in $30 \mathrm{~mL}$ dry $\mathrm{MeCN}$ and was heated to reflux for $2 \mathrm{~d}$. The mixture was cooled to room temperature and $15 \mathrm{~mL}$ saturated $\mathrm{NaCl}$ solution were added. The aqueous layer was extracted three times each with $10 \mathrm{~mL}$ ethyl acetate. The combined organic layers were dried over $\mathrm{MgSO}_{4}$, filtered and the solvent was removed under reduced pressure. The raw product was purified by column chromatography using the Isolera One device with a $25 \mathrm{~g}$ SNAP Ultra cartridge (n-hexane/ethyl acetate, 47:3 to $1: 1, v / v, 20 \mathrm{~mL} / \mathrm{min})$ to obtain $216 \mathrm{mg}\left(15.1 \mu \mathrm{mol}, 79 \%, \mathrm{R}_{f}=0.18\right.$, n-hexane/ethyl acetate, $1: 3, v / v)$ of 7 as an off-white solid. $\mathrm{T}_{\mathrm{m}}: 176-178^{\circ} \mathrm{C}$ (methanol/water). IR (KBr): $\tilde{v}=3436(\mathrm{w}, \mathrm{H}$ bridges $), 3061\left(\mathrm{~m}, v_{\mathrm{sp} 2} \mathrm{H}\right), 2978\left(\mathrm{~m}, v \mathrm{C}_{\mathrm{sp} 3} \mathrm{H}\right), 2929\left(\mathrm{~m}, v \mathrm{C}_{\mathrm{sp} 3} \mathrm{H}\right), 2909\left(\mathrm{~m}, v \mathrm{C}_{\mathrm{sp} 3} \mathrm{H}\right), 2600$ 
(s, vBH), $1740(\mathrm{~m}, v \mathrm{C}=\mathrm{O}), 1640(\mathrm{w}), 1530(\mathrm{~s}, v \mathrm{C}=\mathrm{N}), 1511(\mathrm{~s}, v \mathrm{C}=\mathrm{N}), 1481\left(\mathrm{~s}, \delta \mathrm{CH}_{2}\right), 1422(\mathrm{w}), 1371(\mathrm{w})$, $1316(\mathrm{w}), 1255$ (m), $1219(\mathrm{~m}), 1162$ (s, vCO), $1112(\mathrm{w}), 1070$ (s, vCO), 1011 (s, vBS), $980(\mathrm{~m}), 921(\mathrm{w}), 903$

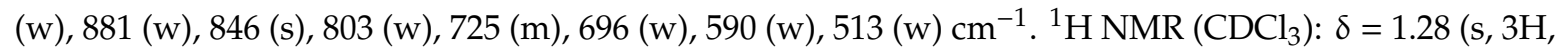
$\left.\mathrm{C}^{18 \text { or } 18^{\prime}} \mathrm{H}_{3}\right), 1.36\left(\mathrm{~s}, 3 \mathrm{H}, \mathrm{C}^{19}\right.$ or $\left.{ }^{19^{\prime}} \mathrm{H}_{3}\right), 1.40\left(\mathrm{~s}, 3 \mathrm{H}, \mathrm{C}^{18 \text { or } 18^{\prime}} \mathrm{H}_{3}\right), 1.42\left(\mathrm{~s}, 3 \mathrm{H}, \mathrm{C}^{19}\right.$ or $\left.19^{\prime} \mathrm{H}_{3}\right), 1.48(\mathrm{~s}, 9 \mathrm{H}$, $\left.\mathrm{C}\left(\mathrm{C}^{9} \mathrm{H}_{3}\right)_{3}\right), 1.54-3.46\left(\mathrm{br}^{\mathrm{a}}, 54 \mathrm{H}, 6 \mathrm{xB}_{10} \mathrm{H}_{9}\right), 1.95$ (s, br, $\left.8 \mathrm{H}, 4 \times \mathrm{C}^{2} \mathrm{H}_{2}\right), 3.59$ (s, br, $\left.8 \mathrm{H}, 8 \times \mathrm{C}^{1} \mathrm{H}\right), 4.14(\mathrm{dd}$, $\left.{ }^{2} \mathrm{~J}_{\mathrm{HH}}=14.5 \mathrm{~Hz},{ }^{3} \mathrm{~J}_{\mathrm{HH}}=3.4 \mathrm{~Hz}, 1 \mathrm{H}, \mathrm{C}^{10} \mathrm{HH}\right), 4.22\left(\mathrm{~m}, 1 \mathrm{H}, \mathrm{C}^{10} \mathrm{HH}\right), 4.35\left(\mathrm{~m}, 4 \mathrm{H}, \mathrm{C}^{11} \mathrm{H}, \mathrm{C}^{13} \mathrm{H}, \mathrm{C}^{14} \mathrm{H}\right.$, $\left.\mathrm{C}^{6} \mathrm{HH}\right), 4.62\left(\mathrm{dd},{ }^{3} J_{\mathrm{HH}}=7.9 \mathrm{~Hz},{ }^{3} J_{\mathrm{HH}}=2.4 \mathrm{~Hz}, 1 \mathrm{H}, \mathrm{C}^{12} \mathrm{H}\right), 4.88\left(\mathrm{~d},{ }^{2} J_{\mathrm{HH}}=17.7 \mathrm{~Hz}, 1 \mathrm{H}, \mathrm{C}^{6} \mathrm{HH}\right), 5.48$ $\operatorname{ppm}\left(\mathrm{d},{ }^{3} \mathrm{~J}_{\mathrm{HH}}=4.9 \mathrm{~Hz}, 1 \mathrm{H}, \mathrm{C}^{15} \mathrm{H}\right) .{ }^{13} \mathrm{C}\left\{{ }^{1} \mathrm{H}\right\} \mathrm{NMR}\left(\mathrm{CDCl}_{3}\right): \delta=24.7,25.2,26.3$ and $26.4\left(\mathrm{~s}, \mathrm{CH}_{3}, \mathrm{C}^{18} \mathrm{H}_{3}\right.$, $\mathrm{C}^{18^{\prime}} \mathrm{H}_{3}, \mathrm{C}^{19} \mathrm{H}_{3}$ and $\left.\mathrm{C}^{19^{\prime}} \mathrm{H}_{3}\right), 27.2\left(\mathrm{~s}, \mathrm{br}, \mathrm{CH}_{2}, \mathrm{C}^{2} \mathrm{H}_{2}\right), 28.4\left(\mathrm{~s}, \mathrm{CH}_{3}, \mathrm{C}\left(\mathrm{C}^{9} \mathrm{H}_{3}\right)_{3}\right), 48.4\left(\mathrm{~s}, \mathrm{CH}_{2}, \mathrm{C}^{10} \mathrm{H}_{2}\right), 50.7$ $\left(\mathrm{s}, \mathrm{CH}_{2}, \mathrm{C}^{6} \mathrm{H}_{2}\right), 55.8\left(\mathrm{~s}, \mathrm{CH}, 8 \times \mathrm{C}^{1} \mathrm{H}\right), 67.2\left(\mathrm{~s}, \mathrm{CH}, \mathrm{C}^{11} \mathrm{H}\right), 71.2\left(\mathrm{~s}, \mathrm{CH}, \mathrm{C}^{14} \mathrm{H}\right), 71.7\left(\mathrm{~s}, \mathrm{CH}, \mathrm{C}^{12} \mathrm{H}\right), 72.4(\mathrm{~s}$, $\left.\mathrm{CH}, \mathrm{C}^{13} \mathrm{H}\right), 75.97,76.05,76.11\left(\mathrm{~s}, \mathrm{C}_{\mathrm{q}}, 4 \times \mathrm{C}_{\mathrm{q}}{ }^{3}\right), 81.6\left(\mathrm{~s}, \mathrm{C}_{\mathrm{q}}, \mathrm{C}_{\mathrm{q}}{ }^{8}\right), 97.1\left(\mathrm{~s}, \mathrm{CH}, \mathrm{C}^{15} \mathrm{H}\right), 109.2\left(\mathrm{~s}, \mathrm{C}_{\mathrm{q}}, \mathrm{C}_{\mathrm{q}}{ }^{17}\right)$, $109.7\left(\mathrm{~s}, \mathrm{C}_{\mathrm{q}}, \mathrm{C}_{\mathrm{q}}{ }^{16}\right), 164.1\left(\mathrm{~s}, \mathrm{C}_{\mathrm{q}}, \mathrm{C}_{\mathrm{q}}{ }^{5}\right), 169.4\left(\mathrm{~s}, \mathrm{C}_{\mathrm{q}}, \mathrm{C}_{\mathrm{q}}{ }^{4}\right), 179.2 \mathrm{ppm}\left(\mathrm{s}, \mathrm{C}_{\mathrm{q}}, \mathrm{C}_{\mathrm{q}}{ }^{7}\right) .{ }^{11} \mathrm{~B}\left\{{ }^{1} \mathrm{H}\right\} \mathrm{NMR}\left(\mathrm{CDCl}_{3}\right): \delta$ $=-19.0(\mathrm{~s}, \mathrm{br}, 4 \mathrm{~B}),-17.3(\mathrm{~s}, 4 \mathrm{~B}),-14.0$ (s, $16 \mathrm{~B}),-13.0(\mathrm{~s}, \mathrm{br}, 6 \mathrm{~B}),-10.0(\mathrm{~s}, 12 \mathrm{~B}),-6.3(\mathrm{~s}, \mathrm{br}, 12 \mathrm{~B}),-4.2$ (s, 2 B, BS), -2.3 ppm (s, br, 4 B, BC). ${ }^{11} \mathrm{~B} \mathrm{NMR}\left(\mathrm{CDCl}_{3}\right): \delta=-18.1$ (m, br, $\left.8 \mathrm{~B}\right),-13.4(\mathrm{~m}, \mathrm{br}, 22 \mathrm{~B}),-10.0$ $\left(\mathrm{d},{ }^{1} J_{\mathrm{BH}}=147 \mathrm{~Hz}, 12 \mathrm{~B}\right),-6.3\left(\mathrm{~d},{ }^{1} J_{\mathrm{BH}}=156 \mathrm{~Hz}, 12 \mathrm{~B}\right),-4.2(\mathrm{~s}, 2 \mathrm{~B}, \mathrm{BS}),-2.3 \mathrm{ppm}(\mathrm{s}, 4 \mathrm{~B}, \mathrm{BC})$. HRMS (ESI+): $\mathrm{C}_{37} \mathrm{H}_{100} \mathrm{~B}_{60} \mathrm{~N}_{4} \mathrm{O}_{7} \mathrm{~S}_{2}, m / z$ calcd: $1427.3121\left([\mathrm{M}+\mathrm{H}]^{+}\right)$; found: 1427.3109 .

\section{Conclusions}

An unusual Kumada-like cross-coupling reaction between three carboranyl-substituted components was employed for the synthesis of a tris-meta-carborane derivative (4), which could be converted to the corresponding tris-meta-carboranyl thiol 6 and successively coupled with tert-butyl-N-(4,6-dichloro-1,3,5-triazin-2-yl)-N-(1', , $2^{\prime}: 3^{\prime}, 4^{\prime}$-di-O-isopropylidene-6' -deoxy- $\alpha$-Dgalactopyranos-6'-yl)glycinate (8) using a modular approach, which was previously successfully employed for the smaller analog, 9-mercapto-1,7-dicarba-closo-dedecaboran(12) [46,47], to give the boron-rich compound 7. Thus, 6 represents a highly facile boron-rich building block for the development of BNCT agents. Compound 7 contains 60 boron atoms, equivalent to a relative boron load of about $45 \%$. After deprotection of the tert-butyl ester group, the resulting carboxylic acid will be suitable for coupling reactions with tumor-selective biomolecules.

Supplementary Materials: The following are available online: Additional synthetic procedures and analytical data for compounds 1, 2, 3, SP1 and SP2; and full crystallographic data for compounds 4, 6, SP1 and SP2 are given in the electronic supplementary information.

Author Contributions: Conceptualization, E.H-H., M.K., B.R. and J.K.; methodology, M.K.; validation, M.K., E.H.-H.; formal analysis, P.L.; investigation, M.L. and P.L.; resources, E.H.-H.; data curation, P.L. and M.K.; writing-original draft preparation, M.K.; writing—review and editing, E.H.-H., P.L., B.R. and J.K.; visualization, M.K.; supervision, E.H.-H.; project administration, E.H.-H.; funding acquisition, E.H.-H.

Funding: Funding by the "Europäischer Fonds für regionale Entwicklung (EFRE)", the Free State of Saxony (ESF) and the Graduate School "Leipzig School of Natural Sciences-Building with Molecules and Nano-objects" (BuildMoNa) are gratefully acknowledged.

Acknowledgments: We thank Ramona Oehme, Susann Billig and Claudia Birkemeyer for measuring the mass spectra, Manuela Roßberg for elemental analysis, Stefanie Märcker-Recklies, Ines Rein and Jaqueline Lewandowski for recording the infrared spectra. We acknowledge support from the German Research Foundation (DFG) and Leipzig University within the program of Open Access Publishing.

Conflicts of Interest: The authors declare the following competing financial interest(s): The work was partly supported by Bayer AG. This work was further supported by the federal state of Saxony, and the "European Regional Development Fund".

\section{References}

1. Locher, G.L. Biological Effects and Therapeutic Possibilities of Neutrons. Am. J. Roentgenol. Radium Therapy 1936, 36, 1-18.

2. Sweet, W.H. The Uses of Nuclear Disintegration in the Diagnosis and Treatment of Brain Tumor. N. Engl. J. Med. 1951, 245, 875-878. [CrossRef] [PubMed] 
3. Hawthorne, M.F. The Role of Chemistry in the Development of Boron Neutron Capture Therapy of Cancer. Angew. Chem. Int. Ed. 1993, 32, 950-984. [CrossRef]

4. Barth, R.F.; Mi, P.; Yang, W. Boron Delivery Agents for Neutron Capture Therapy of Cancer. Cancer Commun. 2018, 38, 35. [CrossRef] [PubMed]

5. Sivaev, I.B.; Bregadze, V.V. Polyhedral Boranes for Medical Applications: Current Status and Perspectives. Eur. J. Inorg. Chem. 2009, 2009, 1433-1450. [CrossRef]

6. Kabalka, G.W. Recent Developments in Boron Neutron Capture Therapy. Expert Opin. Ther. Pat. 1998, 8, 545-551. [CrossRef]

7. Hatanaka, H. A revised Boron-Neutron Capture Therapy for Malignant Brain Tumors. J. Neurol. 1975, 209, 81-94. [CrossRef]

8. Barth, R.F.; Soloway, A.H.; Fairchild, R.G. Boron Neutron Capture Therapy of Cancer. Cancer Res. 1990, 50, 1061-1070. [CrossRef]

9. Soloway, A.H.; Tjarks, W.; Barnum, B.A.; Rong, F.-G.; Barth, R.F.; Codogni, I.M.; Wilson, J.G. The Chemistry of Neutron Capture Therapy. Chem. Rev. 1998, 98, 1515-1562. [CrossRef]

10. Calabrese, G.; Daou, A.; Barbu, E.; Tsibouklis, J. Towards Carborane-functionalised Structures for the Treatment of Brain Cancer. Drug Discov. Today 2018, 23, 63-75. [CrossRef]

11. Sears, V.F. Neutron Scattering Lengths and Cross Sections. Neutron News 1992, 3, 26-37. [CrossRef]

12. Petry, W.; Neuhaus, J. Neutronen nach Maß. Physik J. 2007, 6, 31-37.

13. Pan, X.Q.; Wang, H.; Shukla, S.; Sekido, M.; Adams, D.M.; Tjarks, W.; Barth, R.F.; Lee, R.J. Boron-Containing Folate Receptor-Targeted Liposomes as Potential Delivery Agents for Neutron Capture Therapy. Bioconjugate Chem. 2002, 13, 435-442. [CrossRef]

14. Shukla, S.; Wu, G.; Chatterjee, M.; Yang, W.; Sekido, M.; Diop, L.A.; Müller, R.; Sudimack, J.J.; Lee, R.J.; Barth, R.F.; et al. Synthesis and Biological Evaluation of Folate Receptor-Targeted Boronated PAMAM Dendrimers as Potential Agents for Neutron Capture Therapy. Bioconjugate Chem. 2003, 14, 158-167. [CrossRef]

15. Dubey, R.; Kushal, S.; Mollard, A.; Vojtovich, L.; Oh, P.; Levin, M.D.; Schnitzer, J.E.; Zharov, I.; Olenyuk, B.Z. Tumor Targeting, Trifunctional Dendritic Wedge. Bioconjugate Chem. 2015, 26, 78-89. [CrossRef]

16. Feng, B.; Tomizawa, K.; Michiue, H.; Miyatake, S.-I.; Han, X.-J.; Fujimura, A.; Seno, M.; Kirihata, M.; Matsui, H. Delivery of Sodium Borocaptate to Glioma Cells using Immunoliposome Conjugated with Anti-EGFR Antibodies by ZZ-His. Biomaterials 2009, 30, 1746-1755. [CrossRef] [PubMed]

17. Michiue, H.; Sakurai, Y.; Kondo, N.; Kitamatsu, M.; Bin, F.; Nakajima, K.; Hirota, Y.; Kawabata, S.; Nishiki, T.-I.; Ohmori, I.; et al. The Acceleration of Boron Neutron Capture Therapy using Multi-linked Mercaptoundecahydrododecaborate (BSH) fused Cell-penetrating Peptide. Biomaterials 2014, 35, 3396-3405. [CrossRef]

18. Iguchi, Y.; Michiue, H.; Kitamatsu, M.; Hayashi, Y.; Takenaka, F.; Nishiki, T.-i.; Matsui, H. Tumor-specific Delivery of BSH-3R for Boron Neutron Capture Therapy and Positron Emission Tomography Imaging in a Mouse Brain Tumor Model. Biomaterials 2015, 56, 10-17. [CrossRef]

19. Doi, A.; Kawabata, S.; Iida, K.; Yokoyama, K.; Kajimoto, Y.; Kuroiwa, T.; Shirakawa, T.; Kirihata, M.; Kasaoka, S.; Maruyama, K.; et al. Tumor-specific Targeting of Sodium Borocaptate (BSH) to Malignant Glioma by Transferrin-PEG Liposomes: a Modality for Boron Neutron Capture Therapy. J. Neurooncol. 2008, 87, 287-294. [CrossRef]

20. Romero-Canelón, I.; Phoenix, B.; Pitto-Barry, A.; Tran, J.; Soldevila-Barreda, J.J.; Kirby, N.; Green, S.; Sadler, P.J.; Barry, N.P.E. Arene Ruthenium Dithiolato-carborane Complexes for Boron Neutron Capture Therapy (BNCT). J. Organomet. Chem. 2015, 796, 17-25. [CrossRef]

21. Kettenbach, K.; Schieferstein, H.; Grunewald, C.; Iffland, D.; Reffert, L.M.; Hampel, G.; Schütz, C.L.; Bings, N.H.; Ross, T.L. Synthesis and Evaluation of Boron Folates for Boron-Neutron-Capture-Therapy (BNCT). Radiochim. Acta 2015, 103, 799-809. [CrossRef]

22. Mier, W.; Gabel, D.; Haberkorn, U.; Eisenhut, M. Conjugation of the closo-Borane Mercaptoundecahydrododecaborate (BSH) to a Tumour Selective Peptide. Z. Anorg. Allg. Chem. 2004, 630, 1258-1262. [CrossRef]

23. Lai, C.-H.; Lin, Y.-C.; Chou, F.-I.; Liang, C.-F.; Lin, E.-W.; Chuang, Y.-J.; Lin, C.-C. Design of Multivalent Galactosyl Carborane as a Targeting Specific Agent for Potential Application to Boron Neutron Capture Therapy. Chem. Commun. 2012, 48, 612-614. [CrossRef] [PubMed] 
24. Otero, R.; Seoane, S.; Sigüeiro, R.; Belorusova, A.Y.; Maestro, M.A.; Pérez-Fernández, R.; Rochel, N.; Mouriño, A. Carborane-based Design of a Potent Vitamin D Receptor Agonist. Chem. Sci. 2016, 7, 1033-1037. [CrossRef] [PubMed]

25. Worm, D.J.; Els-Heindl, S.; Kellert, M.; Kuhnert, R.; Saretz, S.; Koebberling, J.; Riedl, B.; Hey-Hawkins, E.; Beck-Sickinger, A.G. A Stable meta-Carborane Enables the Generation of Boron-rich Peptide Agonists Targeting the Ghrelin Receptor. J. Pept. Sci. 2018, 32, e3119. [CrossRef]

26. Ciofani, G.; Raffa, V.; Menciassi, A.; Cuschieri, A. Folate Functionalized Boron Nitride Nanotubes and their Selective Uptake by Glioblastoma Multiforme Cells: Implications for their Use as Boron Carriers in Clinical Boron Neutron Capture Therapy. Nanoscale Res. Lett. 2008, 4, 113-121. [CrossRef] [PubMed]

27. Kueffer, P.J.; Maitz, C.A.; Khan, A.A.; Schuster, S.A.; Shlyakhtina, N.I.; Jalisatgi, S.S.; Brockman, J.D.; Nigg, D.W.; Hawthorne, M.F. Boron Neutron Capture Therapy Demonstrated in Mice Bearing EMT6 Tumors Following Selective Delivery of Boron by Rationally Designed Liposomes. Proc. Natl. Acad. Sci. USA 2013, 110, 6512-6517. [CrossRef] [PubMed]

28. Chadwick, J.; Goldhaber, M. Disintegration by Slow Neutrons. Nature 1935, 135, 65. [CrossRef]

29. Taylor, H.J.; Goldhaber, M. Detection of Nuclear Disintegration in a Photographic Emulsion. Nature 1935, 135, 341. [CrossRef]

30. Hattori, Y.; Kusaka, S.; Mukumoto, M.; Uehara, K.; Asano, T.; Suzuki, M.; Masunaga, S.-I.; Ono, K.; Tanimori, S.; Kirihata, M. Biological Evaluation of Dodecaborate-Containing L-Amino Acids for Boron Neutron Capture Therapy. J. Med. Chem. 2012, 55, 6980-6984. [CrossRef]

31. Hartman, T.; Carlsson, J. Radiation Dose Heterogeneity in Receptor and Antigen-mediated Boron Neutron Capture Therapy. Radiother. Oncol. 1994, 31, 61-75. [CrossRef]

32. Ahrens, V.M.; Frank, R.; Stadlbauer, S.; Beck-Sickinger, A.G.; Hey-Hawkins, E. Incorporation of ortho-Carbaboranyl- $\mathrm{N}_{\varepsilon}$-Modified L-lysine into Neuropeptide $\mathrm{Y}$ Receptor $\mathrm{Y}_{1}$ - and $\mathrm{Y}_{2}$-Selective Analogues. J. Med. Chem. 2011, 54, 2368-2377. [CrossRef] [PubMed]

33. Choi, K.Y.; Saravanakumar, G.; Park, J.H.; Park, K. Hyaluronic Acid-based Nanocarriers for Intracellular Targeting: Interfacial Interactions with Proteins in Cancer. Colloid Surface B 2012, 99, 82-94. [CrossRef] [PubMed]

34. Agosteo, S.; Colautti, P.; Esposito, J.; Fazzi, A.; Introini, M.V.; Pola, A. Characterization of the Energy Distribution of Neutrons generated by $5 \mathrm{MeV}$ Protons on a Thick Beryllium Target at Different Emission Angles. Appl. Radiat. Isotopes 2011, 69, 1664-1667. [CrossRef] [PubMed]

35. Kumada, H.; Matsumura, A.; Sakurai, H.; Sakae, T.; Yoshioka, M.; Kobayashi, H.; Matsumoto, H.; Kiyanagi, Y.; Shibata, T.; Nakashima, H. Project for the Development of the Linac-based NCT Facility in University of Tsukuba. Appl. Radiat. Isotopes 2014, 88, 211-215. [CrossRef] [PubMed]

36. Durisi, E.; Alikaniotis, K.; Borla, O.; Bragato, F.; Costa, M.; Giannini, G.; Monti, V.; Visca, L.; Vivaldo, G.; Zanini, A. Design and Simulation of an Optimized e-Linac-based Neutron Source for BNCT Research. Appl. Radiat. Isotopes 2015, 106, 63-67. [CrossRef]

37. Onishi, T.; Kumada, H.; Takada, K.; Naito, F.; Kurihara, T.; Sakae, T. Investigation of the Neutron Spectrum Measurement Method for Dose Evaluation in Boron Neutron Capture Therapy. Appl. Radiat. Isotopes 2018, 140, 5-11. [CrossRef]

38. Lerouge, F.; Viñas, C.; Teixidor, F.; Núñez, R.; Abreu, A.; Xochitiotzi, E.; Santillan, R.; Farfán, N. High Boron Content Carboranyl-functionalized Aryl Ether Derivatives Displaying Photoluminescent Properties. Dalton Trans. 2007, 92, 1898-1903. [CrossRef]

39. Parrott, M.C.; Marchington, E.B.; Valliant, J.F.; Adronov, A. Synthesis and Properties of Carborane-Functionalized Aliphatic Polyester Dendrimers. J. Am. Chem. Soc. 2005, 127, 12081-12089. [CrossRef]

40. Kawasaki, R.; Sasaki, Y.; Akiyoshi, K. Intracellular Delivery and Passive Tumor Targeting of a Self-assembled Nanogel Containing Carborane Clusters for Boron Neutron Capture Therapy. Biochem. Biophys. Res. Commun. 2017, 483, 147-152. [CrossRef]

41. Mollard, A.; Zharov, I. Tricarboranyl Pentaerythritol-Based Building Block. Inorg. Chem. 2006, 45, 10172-10179. [CrossRef] [PubMed]

42. Nar, I.; Bortolussi, S.; Postuma, I.; Atsay, A.; Berksun, E.; Viola, E.; Ferrari, C.; Cansolino, L.; Ricciardi, G.; Donzello, M.P.; et al. A Phthalocyanine-ortho-Carborane Conjugate for Boron Neutron Capture Therapy: Synthesis, Physicochemical Properties, and in Vitro Tests. ChemPlusChem 2019, 84, 345-351. [CrossRef] 
43. Bregadze, V.I. Dicarba-closo-dodecaboranes $\mathrm{C}_{2} \mathrm{~B}_{10} \mathrm{H}_{12}$ and Their Derivatives. Chem. Rev. 1992, 92, $209-223$. [CrossRef]

44. Fox, M.A.; Gill, W.R.; Herbertson, P.L.; MacBride, J.A.H.; Wade, K. Deboronation of C-Substituted ortho- and meta-closo-Carboranes Using "wet" Fluoride Ion Solutions. Polyhedron 1996, 15, 565-571. [CrossRef]

45. Kellert, M.; Worm, D.J.; Hoppenz, P.; Sárosi, M.B.; Lönnecke, P.; Riedl, B.; Koebberling, J.; Beck-Sickinger, A.G.; Hey-Hawkins, E. Modular Triazine-based Carborane-containing Carboxylic Acids - Synthesis and Characterisation of Potential Boron Neutron Capture Therapy Agents Made of Readily Accessible Building Blocks. Dalton Trans. 2019, 48, 10834-10844. [CrossRef] [PubMed]

46. Kellert, M. s-Triazine-based Boron-rich Carboxylic Acids and Amines. The Journey of Modular Boron Neutron Capture Therapy Precursors with an Enhanced Boron Load. Ph.D. Thesis, Leipzig University, Leipzig, Germany, 2019.

47. Hey-Hawkins, E.; Beck-Sickinger, A.G.; Kellert, M.; Kuhnert, R.; Saretz, S.; Riedl, B.; Bierer, D.; Koebberling, J.; Griebenow, N. Novel 1,7-Dicarba-closo-dodecaborane(12) (meta-Carborane)-derived Carboxylic Acids and Amines Suitable for Peptide Modification for Application in Boron Neutron Capture Therapy (BNCT). WO/2019/115617, 20 June 2019.

48. Timofeev, S.V.; Bregadze, V.I.; Osipov, S.N.; Titanyuk, I.D.; Petrovskii, P.V.; Starikova, Z.A.; Glukhov, I.V.; Beletskaya, I.P. New Carborane-containing Amino Acids and Their Derivatives. Crystal Structures of N-Protected Carboranylalaninates. Russ. Chem. Bull. 2007, 56, 791-797. [CrossRef]

49. Timofeev, S.V.; Prikaznova, E.A.; Starikova, Z.A.; Osipov, S.N.; Bregadze, V.I. Synthesis and Structure of Diethyl (1-benzyloxycarbonylamino-1-carboranyl-3,3,3-trifluoropropyl)phosphonate. Russ. Chem. Bull. 2013, 62, 1934-1937. [CrossRef]

50. Smith, H.D.; Obenland, C.O.; Papetti, S. A New Series of Organoboranes. IX. The Preparation and Some Reactions of Sulfur-Carborane Derivatives. Inorg. Chem. 1966, 5, 1013-1015. [CrossRef]

51. Reiner, J.; Alexander, R.P.; Schröder, H. A New Series of Organoboranes. VIII. The Reaction of Phosgene with the Dilithium Salts of $o$ - and $m$-Carborane. Inorg. Chem. 1966, 5, 1460-1462. [CrossRef]

52. Viñas, C.; Benakki, R.; Teixidor, F.; Casabó, J. Dimethoxyethane as a Solvent for the Synthesis of C-Monosubstituted o-Carborane Derivatives. Inorg. Chem. 1995, 34, 3844-3845. [CrossRef]

53. Bauer, S.; Tschirschwitz, S.; Lönnecke, P.; Frank, R.; Kirchner, B.; Clarke, M.L.; Hey-Hawkins, E. Enantiomerically Pure Bis(phosphanyl)carbaborane(12) Compounds. Eur. J. Inorg. Chem. 2009, 2776-2788. [CrossRef]

54. Tamao, K.; Sumitani, K.; Kumada, M. Selective Carbon-Carbon Bond Formation by Cross-Coupling of Grignard Reagents with Organic Halides. Catalysis by Nickel-Phosphine Complexes. J. Am. Chem. Soc. 1972, 94, 4374-4376. [CrossRef]

55. Zhao, J.; Huang, P.; Chen, G.; Zhan, M. Copper (I)-catalyzed Cross-coupling Reaction for the Synthesis of 1,2-Bis(3-butenyl)-1,2-dicarba-closo-dedocaborane. Inorg. Chem. Commun. 2012, 15, 321-323. [CrossRef]

56. Tamao, K.; Sumitani, K.; Kiso, Y.; Zembayashi, M.; Fujioka, A.; Kodama, S.-i.; Nakajima, I.; Minato, A.; Kumada, M. Nickel-Phosphine Complex-Catalyzed Grignard Coupling. I. Cross-Coupling of Alkyl, Aryl, and Alkenyl Grignard Reagents with Aryl and Alkenyl Halides: General Scope and Limitations. Bull. Chem. Soc. Jpn. 1976, 49, 1958-1969. [CrossRef]

57. Himmelspach, A.; Finze, M. Dicarba-closo-dodecaboranes with One and Two Ethynyl Groups Bonded to Boron. Eur. J. Inorg. Chem. 2010, 2012-2024. [CrossRef]

58. Teixidor, F.; Sillanpää, R.; Pepiol, A.; Lupu, M.; Viñas, C. Synthesis of Globular Precursors. Chem. Eur. J. 2015, 21, 12778-12786. [CrossRef] [PubMed]

59. Puga, A.V.; Teixidor, F.; Sillanpää, R.; Kivekäs, R.; Viñas, C. Synthesis of Quadruped-Shaped Polyfunctionalized $o$-Carborane Synthons. Chem. Commun. 2011, 47, 2252-2254. [CrossRef] [PubMed]

60. Vaca, A.; Teixidor, F.; Kivekäs, R.; Sillanpää, R.; Viñas, C. A Solvent-free Regioselective Iodination Route of ortho-Carboranes. Dalton Trans. 2006, 4884-4885. [CrossRef] [PubMed]

61. Lupu, M.; Zaulet, A.; Teixidor, F.; Sillanpää, R.; Viñas, C. Poly-iodinated-closo-1,2- $\mathrm{C}_{2} \mathrm{~B}_{10}$ and nido-[7,8-C $\left.\mathrm{C}_{2} \mathrm{~B}_{9}\right]^{-}$ Carborane Frameworks: Synthesis and Consequences. J. Organomet. Chem. 2015, 798, 171-181. [CrossRef]

62. Zheng, Z.; Jiang, W.; Zinn, A.A.; Knobler, C.B.; Hawthorne, M.F. Facile Electrophilic Iodination of Icosahedral Carboranes. Synthesis of Carborane Derivatives with Boron-Carbon Bonds via the Palladium-Catalyzed Reaction of Diiodocarboranes with Grignard Reagents. Inorg. Chem. 1995, 34, 2095-2100. [CrossRef]

63. Andrews, J.S.; Zayas, J.; Jones, M., Jr. 9-Iodo-o-carborane. Inorg. Chem. 1985, 24, 3715-3716. [CrossRef] 
64. Wingen, L.M.; Scholz, M.S. B-Cyanodicarba-closo-dodecaboranes: Facile Synthesis and Spectroscopic Features. Inorg. Chem. 2016, 55, 8274-8276. [CrossRef] [PubMed]

65. Zakharkin, L.I. Synthesis and Some Reactions of 1-Halomethyl-m-carboranes. Zh. Obshch. Khim. 1981, 51, 357-361.

66. Li, N.; Zeng, F.; Qu, D.; Zhang, J.; Shao, L.; Bai, Y. Synthesis and Characterization of Carborane-containing Polyester with Excellent Thermal and Ultrahigh Char Yield. J. Appl. Polym. Sci. 2016, 133, 44202. [CrossRef]

67. Goto, T.; Ohta, K.; Suzuki, T.; Ohta, S.; Endo, Y. Design and Synthesis of Novel Androgen Receptor Antagonists with Sterically Bulky Icosahedral Carboranes. Bioorgan. Med. Chem. 2005, 13, 6414-6424. [CrossRef] [PubMed]

68. Zakharkin, L.I. Synthesis of B-organyl-o-and-m-Carboranes by the Cross-Coupling of B-Iodo- $o$-and- $m$-Carboranes with Organozinc Compounds Catalyzed by Palladium Complexes. Russ. J. Gen. Chem. 1998, 68, 925-927.

69. Zakharkin, L.I.; Ol'shevskaya, V.A.; Nesmeyanov's, A.N. Synthesis of 9-Organyl-1,2 and 1,7-Dicarba-closo-dodecaboranes(12) via the Cross-Coupling Reactions Between Organozinc Compounds and 9-Iodo-1,2- or 1,7-Dicarba-closo-dodecaboranes. Syn. React. Inorg. Met.-Org. Chem. 1991, 21, 1041-1046. [CrossRef]

70. Zakharkin, L.I.; Pisareva, I.V. A New Simple Method for the Production and Some Conversions of B-S Bond-containing $o$ - and $m$-Carboranyl. Phosphorus Sulfur 1984, 20, 357-370. [CrossRef]

71. Oae, S.; Takata, T.; Kim, Y.H. Oxidation of Unsymmetrical Disulfide and Thiosuldinic S-Esters with Peroxy Acids. Search for Formation of $\alpha$-Disulfoxide as an Intermediate in the Electrophilic Oxidation of Thiosulfinic S-Ester. Bull. Chem. Soc. Jpn. 1982, 55, 2484-2494. [CrossRef]

72. Harris, R.K.; Becker, E.D.; Cabral de Menezes, S.M.; Goodfellow, R.; Granger, P. NMR Nomenclature: Nuclear Spin Properties and Conventions for Chemical Shifts. IUPAC Recommendations 2001. Pure Appl. Chem. 2001, 73, 1795-1818. [CrossRef]

73. MestReNova; v12.0.0-20080; Mestrelab Research S. L.: Santiago de Compostela, Spain, 2017.

74. CrysAlis Pro: Data Collection and Data Reduction Software Package; Rigaku Oxford Diffraction: Tokyo, Japan, 2015.

75. SCALE3 ABSPACK: Empirical Absorption Correction Using Sperical Harmonics, Implemented in SCALE3 ABSPACK Scaling Algorithm of CrysAlis Pro.; Rigaku Oxford Diffraction: Tokyo, Japan, 2015.

76. Sheldrick, G.M. SHELXT - Integrated space-group and crystal-structure determination. Acta Crystallogr. 2015, A71, 3-8. [CrossRef] [PubMed]

77. Sheldrick, G.M. Crystal structure refinement with SHELXL. Acta Crystallogr. 2015, C71, 3-8. [CrossRef]

78. Brandenburg, K. Diamond; v4.5.3; Crystal Impact GbR: Bonn, Germany, 1997-2019.

Sample Availability: Samples of the compounds are not available from the authors.

(C) 2019 by the authors. Licensee MDPI, Basel, Switzerland. This article is an open access article distributed under the terms and conditions of the Creative Commons Attribution (CC BY) license (http://creativecommons.org/licenses/by/4.0/). 